This is the submitted version of an article published in The International Journal of Educational Organization and Leadership. The final authenticated version is available online at: https://doi.org/10.18848/2329-1656/CGP/v28i02/97-106

\title{
Identity metamorphosis: the "teacher-principal" transition of a female leader for social justice
}

\author{
Cristina Cruz-González, University of Granada, Spain \\ Carmen Lucena Rodríguez ${ }^{1}$, University of Granada, Spain \\ Jesús Domingo Segovia, University of Granada, Spain \\ Javier Mula-Falcón. University of Granada, Spain
}

\begin{abstract}
A growing body of research considers professional leadership identity to be a key element in the professional culture. More specifically, a leadership identity in school principals implies great changes and improvements in the educational outcomes of schools. The identity is unstable and changing. For this reason, the " teacher-principal " transition includes a series of identity changes in education professionals. In this case, we present a case study of a school principal who leads a school with a difficult performance. The findings reveal important changes in the professional identity of this principal and key elements in reference to her identity asymmetry (perceived and assumed).
\end{abstract}

Keywords: professional identity, leadership, female principal, school context

\section{Introduction}

I

dentity is an element of complex definition since it refers to a subjective reality, and is defined through discursive and mental construction (Bolívar, Domingo and Pérez-García 2014). If we refer to professional identity, it is important to point out that this identity is the way we consider ourselves, but also the way we project ourselves to others (Day, Crow and Moller 2017). Vähäsantanen (2015) defines professional identity as a "history of constellations based on the perceptions of teachers as professional actors" (p.3). Authors such as Ricoeur (1996) explain that identity is not something static, but has an unstable and changing nature. For this reason, it is important to focus on research that studies identity construction as a focus. Authors such as Ruohotie-Lyhty (2018) explain that identity construction is a process in which the identity of educational professionals undergoes changes and adaptive modifications as a result of contextual or internal conditions.

Relevant studies in the field of professional identity define the construction of identity as an important process in which not only the protagonist himself intervenes, but also other agents and other contexts that involve him and that have a great involvement in the creation of his professional self (Olsen 2014; Alsup 2006; Beauchamp and Thomas 2009). Stets and Bruke (2000) indicate that identity could be considered as a nucleus composed by a "self as occupant of that role" and a "self and expectations of that role". We consider, therefore, that in studies on professional identity it should be studied in consideration of its characteristics.

In this line, Charles Taylor, assuming the philosophical position of Paul Ricoeur (1991), considers that the subject does not decide the sources of its identity. Based on this position, identity is constructed from social, political and cultural relations with other signifiers (Zarate 2015). This conception of identity that is given by the others, belonging to the same community or not, but that they attribute an identification to the subject is what Sen (2000) denominates attributed identity. This attributed identity and following the same author, is considered blind for the other identities of the person. In this point, for Dubar (2010) the social categorizations are essential and necessarily influence in all the processes of (re)construction of the identity, but

\footnotetext{
${ }^{1}$ Corresponding Author: First Name Last Name, Work Postal Address/Physical Address, Department, Affiliated Organization, City, State, Postal Code, Country. email: address@email.edu
} 
This is the submitted version of an article published in The International Journal of Educational Organization and Leadership. The final authenticated version is available JOURNAL TITLE online at: https://doi.org/10.18848/2329-1656/CGP/v28i02/97-106

they are not necessarily determining, existing for that reason, other subjective identities or assumed by the own subject that coexist in continuous interaction and evolution.

The research of Sen (2000), also manifests opposition to the thoughts of Charles Taylor (2006), because they do not agree in the defense of the consideration of a unique identity attributed that does not allow the criticism that the person can do to his community. On the contrary, he defends the existence of an identity assumed by the own person, linked to the selfidentification of the subject, to its capacity of election and to the consideration of the existence of multiple identities. Therefore, a person necessarily presents an assumed identity (subjective and internal perspective) and an attributed identity (objective and external perspective). In order to achieve good personal and professional development, both identitarian sides must be recognized and live together in a positive approach.

To investigate the identity is not easy, because as it has been argued, it is influenced by numerous personal and external factors to the individual, besides being in continuous change and reconstruction. However, research supports that investigating professional identity gives us understandable clues to know the performance of a subject and understand the reason for their actions (Robertson 2017). Furthermore, authors such as Leithwood and Jantzi (2008) or Crow, Day and Møller (2017), state that strong identities identified in professional practice have a positive impact on educational improvement and that, on the contrary, unstable, weak or poorly identified identities with the function to be performed achieve little educational success. In this sense, a school principal (central object of our study), with a strong and rooted identity, can create unity among the components of the educational community, as well as guide, orient and commit them to a process of educational transformation and school improvement (Quebec, Savoie-Zajc, Landry and Lafortune 2007).

Presenting a strong and tight professional identity is not an easy task. Thus, a school principal is confronted on the one hand with socially and culturally established roles and on the other with those lived and created internally. For example, the fact of being historically immersed in a traditionally patriarchal society, and associating school management with the male gender, can constitute a barrier or limitation in the construction of a principal's identity (Armstrong and Mitchell 2017). Also, in this same sense, as Cruz-González, Lucena and Domingo (2020) state, there are other types of barriers or limitations that affect the construction of the identity of school principals such as context, experience or culture.

Specifically, in the Spanish context in which this study is developed, there is an impact on the identity of a teacher by living an unstable, discontinuous and provisional transition towards a "teacher-director-teacher" directive role (Bolívar and Ritacco 2016; Browne-Ferrigno 2003). This has a notable effect, as the authors themselves state, on their professional performance and on the search for educational improvement.

Another key point of school success, which determines good educational results and the achievement of inclusive schools, is the pedagogical leadership assumed by the management. Leadership, as Bush (2017) states, is understood as that in which a degree of influence is exercised over other school members to achieve the desired objectives and share the vision they have of their school. To do this, it must present a strong and stable leadership identity. In order to know the ways of leadership of a school principal, it is essential to go into his person, requiring access to his personal life, revealing his landmark experiences and people who have had an impact on his life.

Due to the importance of investigating the identity of a school principal to analyse the forms of his leadership and the possible barriers or limitations, the need for this manuscript arises. The present study, which seeks to explore the process of the transition from teacherprincipal identity, is part of two larger research projects. On the one hand, a national $\mathrm{R}+\mathrm{D}+\mathrm{i}$ project entitled "Identity of the director: leadership, training and professionalization" and on the other, the International Successful School Principals Project (ISSPP 2013). Both projects are based on analysing school leadership for educational improvement, including the identification 
of professional identity. Specifically, our manuscript had as its main purpose to explore the process of identity transit in a school leadership principal working in a school of special difficulty (i.e., educational centres that attend families with low economic and cultural levels, as well as low expectations towards education. In short, families at high risk of exclusion (Lyman and Villani 2002). The issues raised by the main objective are presented below.

- What have been the most relevant elements in the construction of this principal's leadership identity?

- What are the main changes experienced in the transit of our principal's "teacher-principal" identity?

The following sections describe the methodology used in this study. The main findings are presented below. First, we examine in depth the more identity-based dimension of the professional development of the female principal participating in this study; second, we analyze what were the main changes experienced in the "teacher-director" identity transit. Finally, we present the discussion and final conclusions.

\section{Methods}

The present study explores the construction of the identity of a female principal in her professional career as a teacher-principal who leads successfully in an educational centre of special difficulty. For this purpose, we used the life history method (Alderton 2017; Keddie and Holloway 2019), thus assuming a hermeneutic, biographical and narrative approach (Bolivar and Domingo 2019; Kelchtermans 1993) which allowed us to know the person, in terms of what she feels, thinks, believes and experiences. This narrative approach, as some studies maintain (Craig 2007; Watson 2006), is fundamental for investigating professional identities and for studying, taking into account the context (social and historical) and the dimensions (spatial and temporal) of human experiences.

\section{Case selection}

In a life history case study, the choice of a good case is of vital importance. Therefore, it is necessary to select exemplary cases (Bolivar and Domingo 2019). In our research, we intentionally selected a unique case based on the main criteria established by the two projects that form the framework of our study:

- Principals who work in a vulnerable context.

- Principals considered by their educational community to be successful school leaders.

- Above-average school educational results according to their socio-cultural context.

In a second step, we implement our own selection criteria through a snowball process:

- Being a female principal

- Presenting a leadership identity

- Adequacy of the case with the objectives set, i.e., female principals who works in a vulnerable context.

- Volunteerism of the informant

\section{Data collection}

In order to deepen the construction of our principal's identity as a subject of study and to know her identity development in the teacher-principal transition process (i.e., identity transformation 
that subjects undergo when their roles change from teacher to leader), it was essential to capture all her key moments, circumstances and critical incidents. To this end, we conducted in-depth interviews of approximately 90 minutes during the years that our study lasted (2018-2020). The studies were carried out intermittently over the years depending on the availability of the subject and the needs of the researchers. In addition to the in-depth biographical interviews, we added other instruments typical of qualitative research, such as participant observation or the analysis of institutional or personal documents. Everything observed and analysed was recorded in the field journal.

\section{Data analysis}

During the information gathering process, its analysis was developed in two main phases: through reflective deepening cascades and critical discourse analysis. After each of the interviews, cascades of reflective deepening (Kelchtermans 1993) were carried out on our participant with the aim of achieving validation of the information collected and also orienting the thematic focus of each interview towards the main objective. Once the information was validated, all the interviews were transcribed and validated by means of a life biogram, allowing us to analyse her whole life and focus on the milestones, leitmotifs, key characters, incidents and/or events developed in her teacher-director identity transition. All this information gathered in the interviews, observations and documentary analysis used for the creation of the life biogram, was turned into a qualitative analysis software (Nvivo 12). This program helped us to manage, order and analyse all the information in a rigorous way.

\section{Ethical considerations}

Finally, it is necessary to add a section dedicated to the ethical considerations implemented in our study. Firstly, it was considered a priority to inform our informant of the methodological process of the research, as well as all the steps to be developed. This aspect was developed through the signing of an ethical commitment that not only explained the research process but also informed about the anonymity of the information. It was also considered essential to build trust, and to this end, going native in the research context itself became paramount.

\section{Limitations}

Finally, we should mention a series of limitations related to the development of this study. Firstly, the difficulty in finding subjects with the right characteristics for the study and with full willingness to participate. Secondly, the numerous criticisms surrounding the methodology employed. This methodology is criticised for its lack of generalisability of the results. Despite this, the literature defends this methodology as the most appropriate for the study of participants' trajectories and experiences (Denzin 2009).

\section{Findings}

In this section we present the results of our study. Firstly, we examine in depth the more identitarian dimension of the professional development of the female principal participating in this study. Then we analyse what were the main changes experienced in the "teacher-principal" identity transit. Finally, we will explore her current professional leadership identity, which has been key to achieving educational improvement in a school of special difficulty.

\section{Professional and personal background}


This is the submitted version of an article published in The International Journal of Educational Organization and Leadership. The final authenticated version is available online at: https://doi.org/10.18848/2329-1656/CGP/v28i02/97-106

FIRST AUTHOR LAST NAME: ARTICLE TITLE

Victoria (pseudonym) was born in 1966 in a rural village in the province of Jaén, Andalusia, Spain. In her childhood, she dreamed of becoming a teacher. Her strong vocation for teaching and childhood were the main reasons why she decided to study Teaching Studies.

When she finished her studies, she began to work as a teacher in schools of different characteristics. In all these professional experiences, she remembers the great enthusiasm with which she faced her work. Victoria explains that she remembers her initial stage as one of the most enriching and happy. After six years working in different schools, Victoria got a stable place in a school in the city where she lives.

This school is a centre for Infant and Primary Education, which includes students from 3 to 12 years old approximately. It is located in a peripheral area of the city and its professional team is unstable, since there are few teachers who have been in this school for a long period of time. The student body is characterized by its cultural and socio-economic diversity. This centre was catalogued by the Andalusian Agency for Educational Evaluation (AGAEVE) as a centre of difficult performance. However, since 2014, the year in which our participant became principal, the school has presented substantial educational improvements such as an increase in academic performance.

One of the main focuses of this study was to analyze her professional identity. Victoria says that this identity has been changing over time, resulting now in her current professional profile. Past professional experiences, her training, having a family, the school contexts in which she worked, the school context in which she currently works... all this has been fundamental in consolidating her identity.

\title{
Building a professional leadership identity: Critical incidents and identity asymmetry (perceived and attributed identity)
}

As we explained in the previous section, Victoria attributes a special influence in the construction of her identity to some vital and professional events that had a decisive impact on her "professional self". Throughout her discourse she also refers to another important nuance, and that is the value of the vision that other professionals have of her professional identity. Victoria said that being a principal is a peculiar figure. This figure differs greatly from the teaching figure, not only because of her functions, but also because of the different capacities and skills to be carried out.

\begin{abstract}
"Being a principal is not only a position, it is also another way of understanding one's profession. I think that more than "being", it is "feeling". That is to say, you must feel that you are a principal, that it is not enough just to do what is stipulated. This may not seem like it, but it's complicated. You have to strike a balance. Many times, people think that being a principal means having more power. They are wrong. For me it is more responsibility to achieve the school that I dream of."
\end{abstract}

At the same time, she points out that she is a very exposed figure and that her relationship and professional bond with others has to be solid and consistent. It must also be based on principles of justice, responsibility, respect, empathy and professional commitment. Victoria adds that

"Throughout my professional career, my identity has been transformed. But the truth is that my essence has always been there. Then, the experiences are a plus, and of course, they make you model your professional style. However, today, after decades of professional practice, I still see the enthusiasm and vocation for which I decided to devote myself to the world of education" 
Victoria argues that this is something that is perceived, and that impacts on the way others consider her.

"To be a principal it is very important that your team recognizes you as a valid, responsible and involved person. That is why I try to project values such as commitment and responsibility onto others through my professional practice. In this case, it is important to be one, but also to transmit it."

She considers that the image she has of herself and the image others may have of her is reasonably approximate. Victoria believes that when you have a long career, many skills and values are already in place and that brings stability and strength to your work. The principal says that she conceives her own professional identity as an identity consolidated by her years of experience, and also with very clear values.

"Everything is given by experience. It makes you stop and think about who I am, what role I can play in making my centre better, what aspects I have to improve, how I can achieve a committed team, and of course, what my team wants for my centre and how we can do it."

\section{Main changes experienced in the "teacher-principal" identity transit}

For more than five years our participant has been the principal of the school where she works. In this case, we wanted to go into the identity changes she experienced when she became the principal.

Victoria explains that the decision to become a principal was not premeditated.

"After so many years at the school, I began to realize that I needed to take on more responsibility. This feeling was motivated by the fact that I saw issues that needed to be improved, and I thought I knew how. The whole educational community had me very much in mind for initiatives and proposals, and I thought, if I feel recognized and capable, if they count on me and believe in me, why not take the step?

Our principal explains that this change was more noticeable than she first believed.

"It's true that I felt very capable, but when you really become a principal you feel a great weight of responsibility. Being a teacher, you have a very important role and you have to strive for a good professional environment, a good teaching for your students...Being a principal, the whole focus is on you. You feel the responsibility of all the students, all the teachers. It seems chaotic, yet when positive changes come, it's wonderful."

The feeling of over-responsibility was one of the main changes that Victoria experienced in her identity transit. However, she adds that with experience one learns to delegate responsibilities, to trust the professional team, and that is really where a leadership identity is formed.

"One is not a better principal by appropriating all the tasks to oneself. You have to give confidence to others, who also make commitments within the school. In this way, we all collaborate and we all feel part of the school"

Another of the main points raised with our participant was the most significant changes in the teacher-principal identity. In this case, Victoria expressed that there are both positive and 
This is the submitted version of an article published in The International Journal of Educational Organization and Leadership. The final authenticated version is available online at: https://doi.org/10.18848/2329-1656/CGP/v28i02/97-106

FIRST AUTHOR LAST NAME: ARTICLE TITLE

negative aspects to this transition. The negative ones are that being a principal implies bureaucratic and administrative responsibilities, which, in spite of the efforts, force you to dedicate less time to pedagogical issues. In addition, the contact with colleagues is transformed into another type of relationship. She adds "you are no longer their peer, many consider you, their boss. I think this is a mistake, I'm just another professional, and through my actions, I try to make them consider me that way. Someone they can trust and rely on."

With regard to the positive aspects, she argues that being a principal also brings with it very positive aspects for personal and professional growth. She explains that being a school principal makes you understand education differently. You see everything in a more global, more panoramic way.

"Since I started being a principal, my professional self has been transformed. I stopped thinking, what can I do to improve my classroom? I started asking myself, what can we do to achieve our dreams for a better school? What does my teaching staff need from me? Are my classmates happy?"

\section{Discussion and conclusions}

The main purpose of this study was to explore the process of teacher-principal identity transit in a school leader who works in a difficult school. Throughout the research process, we aimed to extract comprehensive keys on issues such as self-concept and professional self-esteem, perceived/attributed identity and main changes experienced in the "teacher-principal" identity transit.

Consequently, the findings reveal that professional identity is not static, but changing over time (Ricoeur 1996). Elements such as life and professional experiences, family and personal situations, training and work scenarios are key to the construction of a specific professional profile. This coincides with other studies such as Cruz-González, Pérez and Domingo (2020), Arar and Shapira (2016) or Murakami and Tornsen (2017) which state that circumstantial, personal and social aspects are determining factors in the construction of the professional identity of school leaders.

At the same time, our participant alludes to a complex and different figure, the figure of the principal. That is why the identity transition between the teacher and the principal involves a series of processes and changes in professional identity (Browne-Ferrigno 2003). Being a principal implies a different role, which entails greater responsibility. The complexity of the work itself, the great workload, and external pressures are elements that appear when you are a school principal (Ritacco and Bolivar 2018). That is why becoming a principal, as other impact studies point out, involves a major identity shift in professionals (Matthews and Crow 2003; Newton 2001).

Our findings also highlight the multifaceted nature of identity. As Ricoeur (1991) points out, identity is not just one. According to Victoria, it is just as important to be and feel like a principal as it is to be seen as such by others. That is why studies indicate that a leadership identity must have a solid coherence between what one "feels" and how one is recognized by others.

Victoria highlights the experience as an added value to develop professional school leadership practices. Other studies such as Robertson (2017) or Johnson (2017) agree in this sense, explaining that the experience in school principals was a "plus" when it came to shaping their professional profile and facing challenges through a democratic and committed approach. On the other hand, feeling part of the centre and with professional support was also key for Victoria when she became principal. Studies on leadership and identity suggest that the support of the educational community is key in the teacher-principal transition (Berry and Townsend 2019). Delegating responsibilities, trusting your professional team and horizontal educational 
This is the submitted version of an article published in The International Journal of Educational Organization and Leadership. The final authenticated version is available JOURNAL TITLE online at: https://doi.org/10.18848/2329-1656/CGP/v28i02/97-106

practices are all key elements in an effective leadership centre. In her speech, Victoria also alluded to this and stressed that one of the main functions of school management is to promote it.

Following the presentation of this study on the identity construction of our participating principal, we establish certain questions of interest derived from this research. In first place, numerous studies refer to the complexity in the preparation and initiation phase of school principals. For this reason, we encourage future research to address this issue, and also to promote more training programs that not only focus on the functions proper to the work of school leadership, but also on the more personal and human dimension. At the same time, national and international studies indicate that sometimes a barrier for principals to lead educationally is the great bureaucratic and administrative burden. Therefore, education policy makers should take this aspect into account and promote within the state education regulations a greater pedagogical burden in this figure, freeing it from other functions that limit its main task, to lead a centre to improve student learning.

\section{Acknowledgement}

This study is part of the $\mathrm{R}+\mathrm{D}+\mathrm{i}$ project EDU2016-78191-P and the support for university teacher training FPU16/04621, FPU19/00942 and FPU17/01873.

\section{REFERENCES}

Alderton, Julie. 2017. “Kelly's Story: Transformative Identity Work in Primary Mathematics Teacher Education." Gender and Education 1-16. http://doi.org./10.1080/09540253.2017.1336204.

Arar, Khalid and Tamar Shapira. 2016. "Hijab and Principalship: the Interplay between Belief Systems, Educational Management and Gender among Arab Muslim Women in Israel." Gender and Education 28 (7): $851-866$. https://doi.org/10.1080/09540253.2015.1124070

Armstrong, Denise, and Coral Mitchell. 2017. "Shifting identities. Negotiating Intersections of Race and Gender in Canadian Administrative Contexts." Educational Management $\begin{array}{lllll}\text { Administration } \quad \text { and } \quad \text { Leadership } & 45 & \text { (5): }\end{array}$ http://doi.org./10.1177/1741143217712721

Berry, Jill, and Andrew Townsend. 2019. "Peter's Transition to Headship: What Can we Learn from his Experience about How to Prepare to Make the Transition from Assistant Principal, or Deputy, to Principal or Head Teacher?" Journal of Cases in Educational Leadership 22 (3): 28-42. https://doi.org/10.1177\%2F1555458919848131

Bolívar, Aantonio and Jesús Domingo. 2019. "La Investigación (Auto)Biográfica y Narrativa en Educación” [(Self-)Biographical and Narrative Research in Education]. Barcelona: Octaedro.

Bolívar, Antonio and Maximiliano Ritacco. 2016. "Impacto del Modelo Español de Dirección Escolar en la Identidad Profesional de los Líderes Escolares" [Impact of the Spanish School Management Model on the Professional Identity of School Leaders]. Education Policy Analysis Archives 24, 1-35.

Browne-Ferrigno, Tricia. 2003. "Becoming a Principal: Role Conception, Initial Socialization, Role-Identity Transformation, Purposeful Engagement". Educational administration quarterly 39 (4): 468-503

Bush, Toni. 2018. "Preparation and Induction for School Principals: Global Perspectives". Management in Education 32 (2): 66-71. 
This is the submitted version of an article published in The International Journal of Educational Organization and Leadership. The final authenticated version is available online at: https://doi.org/10.18848/2329-1656/CGP/v28i02/97-106

Craig, Cheryl J. 2007. "Story Constellation: A Narrative Approach to Contextualizing Teachers' Knowledge of School Reform." Teaching and Teacher Education 23 (2): 173-188. http://doi.org./10. 1016/j.tate.2006.04.014.

Cruz-González, Cristina, Lucena, Carmen and Jesús Domingo. 2020. "A Systematic Review of Principals' Leadership Identity from 1993 To 2019". Educational Management $\begin{array}{lllll}\text { Administration } \quad \& \quad \text { Leadership, } & 49 & \text { (1): } & \text { 31-53. }\end{array}$ https://doi.org/10.1177/1741143219896053

Cruz-González, Cristina, Marta Pérez and Jesús Domingo. 2020. "Marta’s story: a Female Principal Leading in Challenge Contexts." School Leadership \& Management, 40 (5): 384-405. https://doi.org/10.1080/13632434.2020.1719401

Denzin, Norman. 2009. Studies in Symbolic Interaction. Bingley, UK: Emerald Group Publishing.

Dubar, Claude. 2010. "Socialisation: CONSTRUCTION of SOCIAL and PROFESSIONAL IDENTITIES." Armand Colin.

Johnson, Lauri. 2017. "The Lives and Identities of UK Black and South Asian Head Teachers. Metaphors of Leadership". Educational Management Administration \& Leadership 45 (5): 842-862. https://doi.org/10.1177/1741143217717279

Keddie, Amanda. 2016. "Academisation, School Collaboration and the Primary School Sector in England: A Story of Six School Leaders." School Leadership \& Management 36 (2): 169- 183. http://doi.org./10.1080/13632434.2016.1196174.

Kelchtermans, Geert. 1993. "Getting the Story, Understanding the Lives: From Career Stories to Teachers' Professional Development." Teaching and Teacher Education (9): 443456. http://doi.org./10. 1016/0742-051X(93)90029-G.

Leithwood, Kenneth, and Doris Jantzi. 2008. "Linking Leadership to Student Learning: The Contributions of Leader Efficacy". Educational administration quarterly 44 (4): 496528.

Lyman, Linda, and Christine Villani. 2002. "The Complexity of Poverty: A Missing Component of Educational Leadership Programs." Journal of School Leadership, 12: 246-280. https://doi.org.10.1177/105268460201200302

Matthews, L Joseph and Gary Crow. 2003. "Being and Becoming a Principal: Role Conceptions for Contemporary Principals and Assistant Principals." Boston, MA: Allyn \& Bacon.

Murakami, Elizabeth and Monika Törnsen. 2017. "Female Secondary School Principals. Equity in the Development of Professional Identities." Educational Management Administration and Leadership, 45 (5): $806-824$. http://doi.org/10.1177/1741143217717273

Newton, Liz. 2001. "Self and Illness: Changing Relationships in Response to Life in the Community Following Prolonged Institutionalisation." The Australian journal of anthropology 12 (2): 166-181.

Ricœur, Paul 1991. "L'identité Narrative." [Narrative identity] Revue des sciences humaines [Social Sciences and Humanities Journal] 95 (221), 35-47.

Ricoeur, Paul. 1996. WSí mismo como Otro" [Oneself as another]. Madrid: Siglo XXI.

Ritacco, Maximiliano and Antonio Bolívar. 2018. "School Principals in Spain: an Unstable Identity. " International Journal of Educational Leadership and Managment 6 (1): 1839. https://doi.org/10.17853/ijelm.2018.2110

Robertson, Sylvia. 2017. "Transformation of Professional Identity in an Experienced Primary School Principal. A New Zealand Case Study" Educational Management $\begin{array}{llllll}\text { Administration } \quad \& \quad \text { Leadership } & 45 & \text { (5): } & 774- & 789 .\end{array}$ https://doi.org/10.1177/1741143217707519

Savoie-Zajc, Lorraine, Landry, Reinelde and Louise Lafortune. 2007. "Représentations de Directions D'établissement Scolaire quant à leur Rôledans des Contextes de 
This is the submitted version of an article published in The International Journal of Educational Organization and Leadership. The final authenticated version is available JOURNAL TITLE online at: https://doi.org/10.18848/2329-1656/CGP/v28i02/97-106

Changements Complexes" [Representations of School Principals Regarding their Role in Complex Contexts of Change]. In Christiane Gohier (Dir.) Identités professionnelles d'acteurs de l'enseignement [Professional identities of those involved in education], pp. 257-281. Editorial in University of Québec.

Sen, Amartya. 2000). "La Razón antes que la Identidad. Letras Libres [Reason before Identity. Free Letters]". Año II 23: 14-18.

Taylor, Charles. 2006. "Las Fuentes del yo" [The Sources of self]. Barcelona: Paidós.

Watson, Cate. 2006. "Narratives of Practice and the Construction of Identity in Teaching." Teachers and Teaching: Theory and Practice 12: 509-526. http://doi.org./10.1080/13540600600832213.

Zárate Ortiz, José Francisco. 2015. "La Identidad como Construcción Social desde la Propuesta de Charles Taylor" [Identity as a Social Construction from the Proposal of Charles Taylor]. Eidos (23): 117-134.

\section{ABOUT THE AUTHORS}

Cristina Cruz González: Teaching and Research Staff, Department of Didactics and School Organization, University of Granada, Granada, Spain

Carmen Lucena Rodríguez: Teaching and Research Staff, Department of Didactics and School Organization, University of Granada, Granada, Spain

Jesús Domingo Segovia: University Professor, Department of Didactics and School Organization, University of Granada, Granada, Spain

Javier Mula-Falcón: Teaching and Research Staff, Department of Didactics and School Organization, University of Granada, Granada, Spain 